\title{
Late Quaternary fluctuations of biogenic component fluxes on the continental slope of the Ross Sea, Antarctica
}

\author{
L. Ceccaroni ${ }^{\text {a }}$, M. Frank ${ }^{\text {b,1 }}$, M. Frignani ${ }^{\text {a }}$, L. Langone ${ }^{\mathrm{a}, *}$, M. Ravaioli a , \\ A. Mangini ${ }^{b}$ \\ a Istituto per la Geologia Marina, CNR, via Gobetti 101, 40129 Bologna, Italy \\ ${ }^{\mathrm{b}}$ Heidelberger Akademie der Wissenschaften-INF 366, 69120 Heidelberg, Germany
}

Received 15 September 1995; accepted 15 October 1996

\begin{abstract}
A sediment core, collected from the western part of the continental slope of the Ross Sea at $2380 \mathrm{~m}$ water depth, records events of the last two climatic cycles $(250 \mathrm{kyr}) . \mathrm{A}{ }^{230} \mathrm{Th}_{\mathrm{ex}}$-based chronology was obtained and boundaries of the isotope stages were set assuming that biological productivity was enhanced during periods of less ice cover. Then, ${ }^{230} \mathrm{Th}_{\mathrm{ex}}^{0}$, organic carbon, biogenic silica and biogenic Ba distributions were compared to the glacial-interglacial stage boundaries and corresponding ages of the $\delta^{18} \mathrm{O}$ record of Martinson et al. [Martinson, D.G., Pisias, N.G., Hays, J.D., Imbrie, J., Moore, T.C., Jr., Shackleton, N.J, 1987. Age dating and the orbital theory of the ice ages: development of a high-resolution 0 to 300,000-year chronostratigraphy. Quaternary Research, 27: 1-29]. Sediment accumulation rates ranged between $1.2 \mathrm{~cm}$ $\mathrm{kyr}^{-1}$ in the isotope stage 6 and $3.8 \mathrm{~cm} \mathrm{kyr}^{-1}$ during the Holocene. Variations in the concentrations and fluxes of organic carbon, biogenic $\mathrm{Ba}$, biogenic silica and $\mathrm{Mn}$ gave information on palaeoclimate changes. Processes of sediment redistribution in the Ross Sea margin were enlightened from a comparison of the measured and expected fluxes of ${ }^{230} \mathrm{Th}_{\mathrm{ex}}$. Calculation of the focusing-corrected accumulation rates of biogenic Ba enabled us to evaluate the export palaeoproductivity. Corrected accumulation rates of biogenic components and calculated palaeoproductivities were low, compared to the Antarctic Polar Front in the Atlantic sector, throughout the last two climatic cycles. Glacial-interglacial changes of sea ice cover and ventilation of the Ross Sea were probably major causes of variations in biogenic particle flux and distribution of redox-sensitive elements within the sediment column.
\end{abstract}

\section{Résumé}

Une carotte de sédiment récoltée dans la partie occidentale de la pente continentale de la Mer de Ross, à $2380 \mathrm{~m}$ de profondeur, présente l'enregistrement des évènements survenus pendant les deux derniers cycles climatiques $(250,000$ ans). Une chronologie basée sur le ${ }^{230} \mathrm{Th}_{\mathrm{ex}}$ a été établie, et les limites des stades isotopiques ont été fixées en admettant que la productivité biologique était plus forte pendant les périodes de moindre couverture par les glaces. Les distributions de ${ }^{230} \mathrm{Th}_{\mathrm{ex}}^{0}$, de carbone organique, de silice biogène et de Ba biogène ont été comparées aux limites des stades glaciaires-inter-

\footnotetext{
* Corresponding author. Tel.: +39-51-639-8870; Fax: +39-51-639-8940; E-mail: langone@igm.bo.cnr.it

${ }^{1}$ Present address: Department of Earth Sciences, University of Oxford, Parks Road, Oxford, OX1 3PR, England.
} 
glaciaires et aux âges qui leur correspondent selon les données de $\delta^{18} \mathrm{O}$ de Martinson et al. [Martinson, D.G., Pisias, N.G., Hays, J.D., Imbrie, J., Moore, T.C., Jr., Shackleton, N.J, 1987. Age dating and the orbital theory of the ice ages: development of a high-resolution 0 to 300,000-year chronostratigraphy. Quaternary Research, 27: 1-29]. Les taux d'accumlation sédimentaire ont varié entre $1.2 \mathrm{~cm} \mathrm{ky}^{-1}$ pendant le stade isotopique 6 et $3.8 \mathrm{~cm} \mathrm{ky}^{-1}$ pendant l'Holocène. Les variations dans les concentrations et les flux de carbone organique, de Ba biogène, de silice biogène et de Mn ont fourni des informations sur les changements paléoclimatiques. Le processus de redistribution des sédiments à la marge de la Mer de Ross sont mis en lumière par une comparaison entre les flux mesurés et attendus de ${ }^{230} \mathrm{Th}_{\mathrm{ex}}$. Le calcul des taux d'accumulation de $\mathrm{Ba}$ biogène nous ont permis, après correction des apports advectifs, d'évaluer la paléoproductivité exportée. Par comparaison avec le secteur atlantique de la zone du Front Polaire antarctique, les taux corrigés d'accumulation des substances biogènes et la paléoproductivité calculée étaient faibles pendant toute la durée des deux derniers cycles climatiques. Les changements, entre périodes glaciaires et interglaciaires, dans la couverture par les glaces et la ventilation de la Mer de Ross ont probablement été les principales causes de variation des flux de particules biogènes et de la distribution, dans la colonne sédimentaire, des éléments sensibles aux conditions d'oxydo-réduction. (C) 1998 Elsevier Science B.V. All rights reserved.

Keywords: ${ }^{230} \mathrm{Th}_{\mathrm{ex}}$; glacial-interglacial; sediment core; palaeoproductivity; Ross Sea

\section{Introduction}

The Southern Ocean, being one of the principal sources of oceanic bottom water, plays a key role in governing global ocean circulation, marine climate and biogeochemistry. In particular, a delicate interaction between climate and biological activity exists. Climatically driven features, such as fluctuations of the extent of ice-sheets and ice-shelves, abundance of drifting icebergs and the pattern of water circulation, have influenced productivity and sedimentation. Southern Ocean sediments appear particularly sensitive to climate variations and effective in recording them.

Over the last decade, many palaeoceanographical studies based on sediment records were carried out in the Atlantic and Pacific Sectors of the Southern Ocean, to find evidence for Quaternary primary productivity changes, using indicators such as biogenic silica (Ledford-Hoffman et al., 1986; Burckle and Burak, 1988; Abelmann and Gersonde, 1991; DeMaster et al., 1991), organic carbon (Pedersen and Calvert, 1990) and biogenic Ba (Dehairs et al., 1991; Frank et al., 1995). North of the Antarctic Polar Front (APF) a higher productivity was found during glacials, whereas south of the APF the situation is just the opposite and the palaeoproductivity was higher during interglacials (Mortlock et al., 1991; Charles et al., 1991; Kumar et al., 1993; Shimmield et al., 1994).
Due to the lack of biogenic carbonate and the masking by short-term meltwater events, the establishment of a stratigraphy for Southern Ocean sediments on the basis of $\delta^{18} \mathrm{O}$ is often difficult or impossible. Therefore, naturally occurring radionuclides $\left({ }^{230} \mathrm{Th},{ }^{231} \mathrm{~Pa},{ }^{10} \mathrm{Be}\right)$ have been used to obtain a sedimentary chronology and to establish rates of sediment and biocomponent accumulation south of the APF (Kumar et al., 1993; Shimmield et al., 1994; Frank et al., 1995).

A general model of glaciomarine sedimentation (controlled by biological productivity, ice rafting, currents and gravitational downslope transport) and palaeoenvironmental changes at the Weddell Sea continental margin was proposed by Grobe and Mackensen (1992). In their model, the sediment accumulation rates decrease with increasing distance from the continent. Higher rates occur at the very beginning of interglacials, caused by strongly enhanced productivity, while glacials generally display lower accumulation rates. In addition, lateral transport of sediment and suspended biogenic particles was observed in the bottom water layers at many sites all around Antarctica (e.g., Pudsey, 1992) and it has to be taken into account as an important factor in controlling accumulation rates and element fluxes to the sediments (Frank et al., 1995).

The principal aim of our study was to gain information on the influence of climatic changes on palaeoproductivity through the analysis of deposition 
rates of biogenic indicators such as organic carbon, silica and barium, in the western Ross Sea continental slope, where less data than in the Atlantic Sector are available at the present.

\section{Study area}

The Antarctic continental margin is an important region for the renewal of the deepest waters of the world ocean. In this area, the Circumpolar Deep Water reaches the sea surface and is transformed into a variety of surface, slope and shelf waters (Jacobs, 1991). Water mixing at the continental slope greatly influences the surface productivity and hence the supply of biogenic material to the sediment (Anderson et al., 1979). The Antarctic Slope Front is marked by strong subsurface gradients in ocean temperature and chemical component concentrations, and by strong (up to $15 \mathrm{~cm} \mathrm{~s}^{-1}$ ) contour currents which flow from east to west along the slope (Jacobs, 1991).

The core examined in this study was collected in the western Ross Sea continental slope between Cape

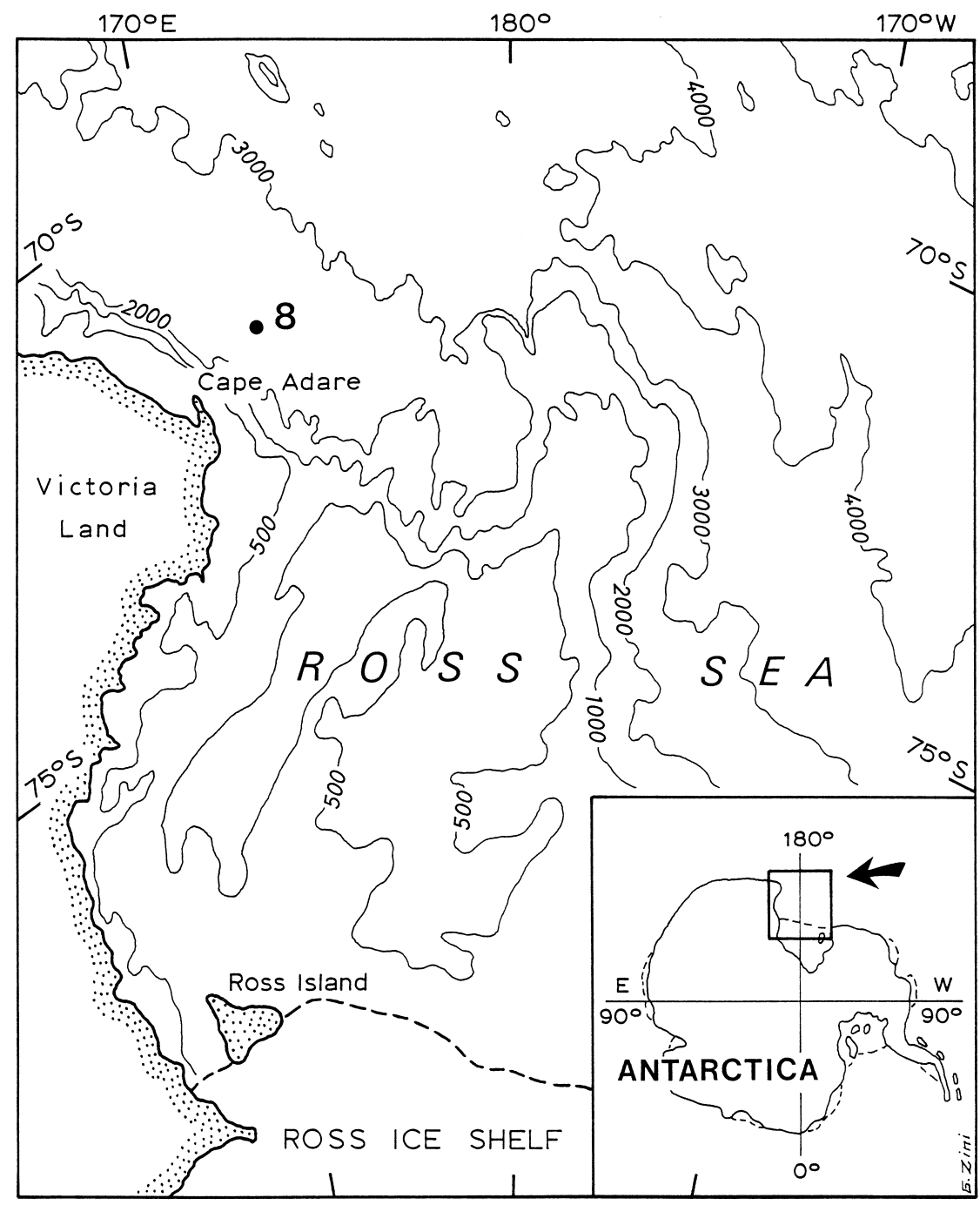

Fig. 1. Study area and sampling site. 
Adare and Iselin Bank (Fig. 1). The morphology of this part of the Ross Sea margin is characterised by the following features: (i) the shelf break is situated at a depth of 500-600 m; (ii) the continental slope is steep, quite sinuous and cut by large submarine canyons: the upper part extends down to $2100 \mathrm{~m}$, then a midslope bench lies between 2100 and 2500 $\mathrm{m}$, with the lower slope occurring at greater water depth.

The sampling site ANTA91-8 $\left(70^{\circ} 47^{\prime} \mathrm{S} 172^{\circ} 50^{\prime} \mathrm{E}\right.$; $2383 \mathrm{~m}$ water depth) was chosen to obtain a sediment core long enough to cover the last $300 \mathrm{kyr}$ and thus the last two climatic cycles.

\section{Materials and methods}

The sediment core, $511 \mathrm{~cm}$ long, was collected using a gravity corer during the Italian cruise of the Progetto Nazionale di Ricerche in Antartide (PNRA) in 1990-1991. The core was X-radiographed, scanned for magnetic susceptibility and then split into two halves. After visual description, continuous slit samples were taken for ${ }^{230} \mathrm{Th}$ analyses using 25 $\mathrm{cm}$ long trays covering the complete length of the core. Sediment slices of $1-4 \mathrm{~cm}$ were sampled for the other analyses. Samples were dried at $60^{\circ} \mathrm{C}$ and then disaggregated or ground.

Whole-core volume magnetic susceptibility was measured using a loop sensor and a Bartington meter, as described by Frignani et al. (1995); readings were taken every $2 \mathrm{~cm}$.

After complete dissolution of the sediment sample, chemical separation of ${ }^{230} \mathrm{Th},{ }^{238} \mathrm{U}$ and ${ }^{234} \mathrm{U}$ and electrodeposition on stainless steel disks were carried out following the procedure of Frank et al. (1994). Radioisotope activities were measured via alphaspectrometry. Average statistical uncertainties $(1 \sigma)$ were in the range of 5\% for the younger samples and increased with age. $\mathrm{Al}, \mathrm{Ba}$ and $\mathrm{Mn}$ were measured by Atomic Absorption Spectrometry, after sample melting with Li-metaborate and complete dissolution, with an average uncertainty of about $5 \%$. Biogenic $\mathrm{Ba}$ was calculated from $\mathrm{Ba}$ and $\mathrm{Al}$ concentrations following Dymond et al. (1992). Analyses of organic carbon were carried out using a gas chromatograph (Carlo Erba CHN EA 1108); the carbonate fraction was eliminated by previous treatment with $1.5 \mathrm{M} \mathrm{HCl}$ in a special silver capsule. The errors associated with organic carbon determinations are $1-3 \%$. Biogenic silica was determined following the progressive dissolution method of DeMaster $(1979,1981)$ and the colorimetric analysis of Strickland and Parsons (1972); $0.5 \mathrm{M} \mathrm{NaOH}$ was used as extracting agent and the uncertainty is about $10 \%$.

\section{Results and discussion}

\subsection{Depth profiles of ${ }^{230} T h_{e x}$, proxy elements and stratigraphy}

Results of core ANTA91-8 are reported in Table 1 . In this core, sediment consists of silty clay alternating with clayey silt. ${ }^{230} \mathrm{Th}_{\mathrm{ex}}$ activities, calculated by subtraction of the detrital radioactive equilibrium activity of ${ }^{234} \mathrm{U}$ from the measured activity of ${ }^{230} \mathrm{Th}$, were significant down to $5 \mathrm{~m}$ depth. An exponential fit (not shown) to the ${ }^{230} \mathrm{Th}_{\mathrm{ex}}$ activity profile yields an approximate average sedimentation rate of $1.7 \mathrm{~cm}$ $\mathrm{kyr}^{-1}$. According to this result the core represents the last 300 kyr. However, as displayed in Fig. 2, the ${ }^{230} \mathrm{Th}_{\text {ex }}$ profile shows large deviations from an exponential decrease. This reflects variable dilution with either terrigenous or biogenic material. A comparison of depth profiles of ${ }^{230} \mathrm{Th}_{\mathrm{ex}}$ and magnetic susceptibility (Fig. 2) shows that peak concentrations of ${ }^{230} \mathrm{Th}_{\mathrm{ex}}$ coincide with maxima of susceptibility, suggesting that the observed pattern is caused by a common dilution phase. On this assumption, we normalised the concentration of ${ }^{230} \mathrm{Th}_{\mathrm{ex}}$ to magnetic susceptibility obtaining a curve closer to an exponential decrease (Fig. 2). Sediment compaction did not influence the magnetic susceptibility profile, as no particular depth trend is shown by the bulk dry density (Fig. 2). An average sedimentation rate of $1.6 \pm 0.4 \mathrm{~cm} \mathrm{kyr}^{-1}$ was obtained from the normalised ${ }^{230} \mathrm{Th}_{\mathrm{ex}}$ profile, using a constant flux-constant sedimentation model. This value is similar to the previous $1.7 \mathrm{~cm} \mathrm{kyr}^{-1}$, but is affected by a much lower uncertainty. This rate was used to estimate a first approximate age for each sample (Table 1). Using this approximate age, the ${ }^{230} \mathrm{Th}_{\mathrm{ex}}$ of each sample was decay corrected to obtain the values of ${ }^{230} \mathrm{Th}_{\mathrm{ex}}^{0}$ (i.e., the ${ }^{230} \mathrm{Th}_{\mathrm{ex}}$ concentration at the time of deposition). 
Table 1

Basic results relative to core Anta91-8

\begin{tabular}{|c|c|c|c|c|c|c|c|c|c|}
\hline $\begin{array}{l}\text { Depth } \\
(\mathrm{cm})\end{array}$ & $\begin{array}{l}\text { Age } \\
(\mathrm{kyr})\end{array}$ & $\begin{array}{l}\text { Bulk dry } \\
\text { density } \\
\left(\mathrm{g} \mathrm{cm}^{-3}\right)\end{array}$ & $\begin{array}{l}{ }^{234} \mathrm{U} \\
\left(\mathrm{dpm} \mathrm{g} \mathrm{g}^{-1}\right)\end{array}$ & $\begin{array}{l}{ }^{230} \mathrm{Th}_{\mathrm{ex}} \\
\left(\mathrm{dpm} \mathrm{g} \mathrm{g}^{-1}\right)\end{array}$ & $\begin{array}{l}\text { Avg. } \\
\text { magnetic } \\
\text { susceptibility } \\
\left(10^{-6} \mathrm{SI}\right)\end{array}$ & $\begin{array}{l}\text { Organic } \\
\text { carbon } \\
(w t . \%)\end{array}$ & $\begin{array}{l}\text { Biogenic } \\
\text { silica } \\
\text { (wt.\%) }\end{array}$ & $\begin{array}{l}\mathrm{Ba} \\
\left(\mu \mathrm{gg}^{-1}\right)\end{array}$ & $\begin{array}{l}\text { Al } \\
\text { (wt.\%) }\end{array}$ \\
\hline $0-7$ & 4.38 & 0.93 & $1.9 \pm 0.3$ & $5.5 \pm 0.3$ & 370 & 0.41 & 7.8 & 1160 & 5.0 \\
\hline $7-15$ & 9.38 & 0.92 & $1.6 \pm 0.2$ & $4.8 \pm 0.3$ & 403 & 0.31 & 10.4 & 970 & 5.1 \\
\hline $15-25$ & 15.6 & 0.91 & $1.4 \pm 0.18$ & $4.6 \pm 0.3$ & 365 & 0.31 & 6.43 & 870 & 5.1 \\
\hline $45-53$ & 33.1 & 0.92 & $2.4 \pm 0.3$ & $3.1 \pm 0.3$ & 504 & 0.45 & 5.18 & 760 & 5.4 \\
\hline $53-63$ & 39.4 & 0.86 & $2.2 \pm 0.3$ & $3.8 \pm 0.3$ & 527 & 0.35 & 4.42 & 790 & 5.8 \\
\hline $63-73$ & 45.6 & 0.86 & $2.8 \pm 0.3$ & $3.5 \pm 0.4$ & 632 & 0.36 & & 770 & 5.7 \\
\hline $73-83$ & 51.9 & 1.00 & $2.1 \pm 0.2$ & $5.0 \pm 0.2$ & 836 & 0.30 & 5.26 & 810 & 5.8 \\
\hline $83-93$ & 58.1 & 1.00 & $1.9 \pm 0.2$ & $5.7 \pm 0.4$ & 765 & 0.17 & 4.11 & 990 & 6.0 \\
\hline $133-138$ & 86.3 & 0.96 & $2.2 \pm 0.16$ & $3.0 \pm 0.3$ & 508 & 0.23 & 6.41 & 920 & 6.1 \\
\hline $138-148$ & 92.5 & 0.98 & $1.6 \pm 0.15$ & $3.0 \pm 0.3$ & 502 & 0.28 & 8.67 & 980 & 6.3 \\
\hline $148-158$ & 98.8 & 0.98 & $2.1 \pm 0.2$ & $2.4 \pm 0.3$ & 562 & 0.42 & 4.77 & 870 & 6.9 \\
\hline $158-168$ & 105.0 & 0.93 & $1.7 \pm 0.18$ & $2.7 \pm 0.3$ & 685 & 0.18 & 4.51 & 1060 & 6.2 \\
\hline $168-178$ & 111.3 & 0.95 & $1.5 \pm 0.19$ & $3.7 \pm 0.3$ & 735 & 0.14 & 5.7 & 1070 & 5.3 \\
\hline $178-188$ & 117.5 & 1.03 & $1.5 \pm 0.17$ & $3.1 \pm 0.2$ & 656 & 0.26 & 5.77 & 950 & 5.5 \\
\hline $188-198$ & 123.8 & 1.14 & $1.3 \pm 0.12$ & $2.8 \pm 0.2$ & 786 & 0.17 & 5.7 & 970 & 5.5 \\
\hline $198-208$ & 130.0 & 0.96 & $1.5 \pm 0.13$ & $2.3 \pm 0.2$ & 929 & 0.15 & 3.59 & 1160 & 5.6 \\
\hline $208-217$ & 135.6 & 0.87 & $1.4 \pm 0.08$ & $2.1 \pm 0.2$ & 668 & 0.16 & 7.16 & 1370 & 5.1 \\
\hline $217-227$ & 141.9 & 0.82 & $1.3 \pm 0.16$ & $1.8 \pm 0.2$ & 582 & 0.18 & 12.2 & 1620 & 5.5 \\
\hline $227-238$ & 148.8 & 0.79 & $1.4 \pm 0.17$ & $0.7 \pm 0.2$ & 563 & 0.17 & 5.62 & 1300 & 5.5 \\
\hline $318-328$ & 205.0 & 0.91 & $2.0 \pm 0.19$ & $1.3 \pm 0.2$ & 571 & 0.14 & 10.9 & & \\
\hline $328-338$ & 211.3 & 0.87 & $1.4 \pm 0.3$ & $1.2 \pm 0.3$ & 534 & 0.16 & 11.5 & 1610 & 5.0 \\
\hline $338-348$ & 217.5 & 0.95 & $1.6 \pm 0.14$ & $0.9 \pm 0.2$ & 645 & 0.18 & 11.5 & & \\
\hline $348-358$ & 223.8 & 1.00 & $1.9 \pm 0.12$ & $0.5 \pm 0.1$ & 740 & 0.16 & & 990 & \\
\hline $358-368$ & 230.0 & 0.93 & $2.0 \pm 0.12$ & $0.3 \pm 0.2$ & 627 & 0.14 & & & \\
\hline $368-378$ & 236.3 & 0.89 & $2.6 \pm 0.17$ & $0.2 \pm 0.2$ & 560 & 0.19 & 13.1 & 910 & 5.5 \\
\hline $378-388$ & 242.5 & 0.95 & $2.0 \pm 0.13$ & $0.9 \pm 0.2$ & 301 & 0.24 & 12.3 & 1050 & 5.4 \\
\hline $388-398$ & 248.8 & 1.04 & $2.4 \pm 0.18$ & $1.1 \pm 0.2$ & 258 & 0.33 & 10.3 & & \\
\hline $398-408$ & 255.0 & 0.87 & $2.2 \pm 0.16$ & $1.2 \pm 0.2$ & 297 & 0.19 & 6.21 & 1160 & 5.6 \\
\hline $408-418$ & 261.3 & 0.94 & $1.8 \pm 0.12$ & $0.7 \pm 0.1$ & 380 & 0.10 & & & \\
\hline $418-428$ & 267.5 & 0.89 & $1.6 \pm 0.12$ & $0.3 \pm 0.1$ & 541 & 0.13 & & & \\
\hline $428-438$ & 273.8 & 0.97 & $2.3 \pm 0.19$ & $0.7 \pm 0.2$ & 385 & 0.34 & & 1080 & 6.4 \\
\hline $438-448$ & & 0.92 & & & 401 & 0.11 & & & \\
\hline $448-458$ & & 0.95 & & & 474 & 0.14 & & 1110 & 5.8 \\
\hline $458-468$ & & 1.07 & & & 466 & 0.15 & & & \\
\hline $468-478$ & & 0.92 & & & 529 & 0.09 & & 1300 & 5.4 \\
\hline
\end{tabular}


Table 1 (continued)

\begin{tabular}{|c|c|c|c|c|c|c|c|c|c|}
\hline $\begin{array}{l}\text { Depth } \\
(\mathrm{cm})\end{array}$ & $\begin{array}{l}\text { Age } \\
(\mathrm{kyr})\end{array}$ & $\begin{array}{l}\text { Bulk dry } \\
\text { density } \\
\left(\mathrm{g} \mathrm{cm}^{-3}\right)\end{array}$ & $\begin{array}{l}{ }^{234} \mathrm{U} \\
\left(\mathrm{dpm} \mathrm{g} \mathrm{g}^{-1}\right)\end{array}$ & 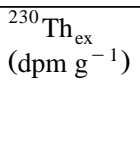 & $\begin{array}{l}\text { Avg. } \\
\text { magnetic } \\
\text { susceptibility } \\
\left(10^{-6} \mathrm{SI}\right)\end{array}$ & $\begin{array}{l}\text { Organic } \\
\text { carbon } \\
\text { (wt.\%) }\end{array}$ & $\begin{array}{l}\text { Biogenic } \\
\text { silica } \\
\text { (wt.\%) }\end{array}$ & $\begin{array}{l}\mathrm{Ba} \\
\left(\mu g^{-1}\right)\end{array}$ & $\begin{array}{l}\mathrm{Al} \\
(\mathrm{wt} . \%)\end{array}$ \\
\hline $478-488$ & & 0.92 & & & 414 & 0.10 & & & \\
\hline $488-499$ & & 0.94 & & & 420 & 0.06 & & 1350 & 5.2 \\
\hline $499-511$ & & 0.94 & & & 373 & 0.18 & & & \\
\hline
\end{tabular}

Ages are related to the lower side of core segments. They were calculated from a ${ }^{230} \mathrm{Th}_{\mathrm{ex}}$ profile after normalization for magnetic susceptibility using a constant flux-constant sedimentation model.

An improved core stratigraphy was obtained based on the assumption that biological productivity was enhanced during periods with less sea-ice cover. We thus ascribed maxima of biogenic $\mathrm{Ba}$, biogenic silica, and organic carbon to interglacial stages and minima to glacial stages (Fig. 3). Then, we set isotope stage boundaries and ages according to the $\delta^{18} \mathrm{O}$ record of Martinson et al. (1987).

The sequence of biogenic $\mathrm{Ba}$, biogenic silica, organic carbon, $\mathrm{U}, \mathrm{Mn}$ and ${ }^{230} \mathrm{Th}_{\mathrm{ex}}$ concentrations is

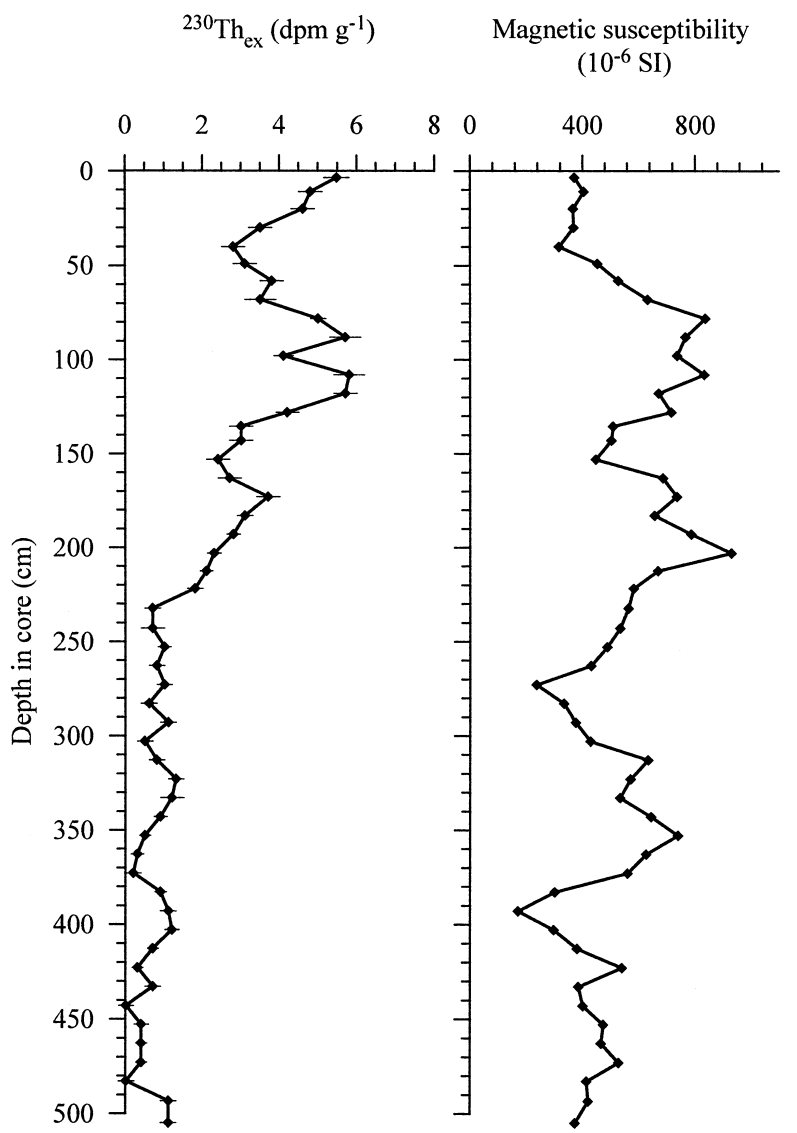

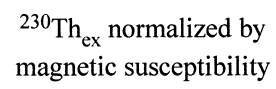

${ }^{230} \mathrm{Th}_{\mathrm{ex}}$ normalized by magnetic susceptibility

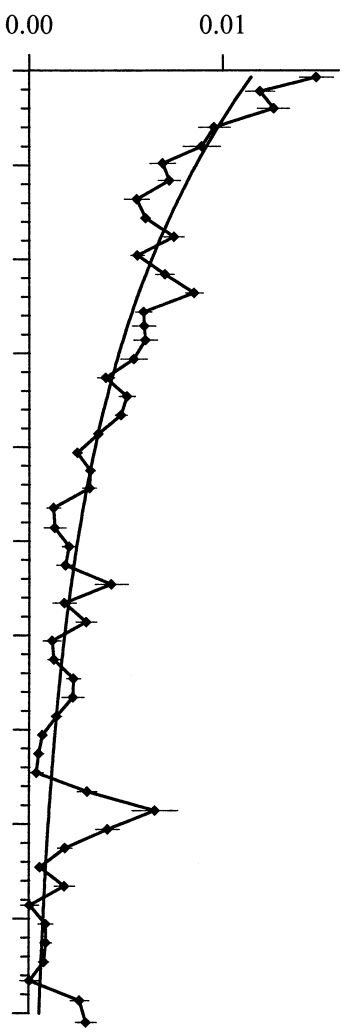

Bulk dry density $\left(\mathrm{g} \mathrm{cm}^{-3}\right)$

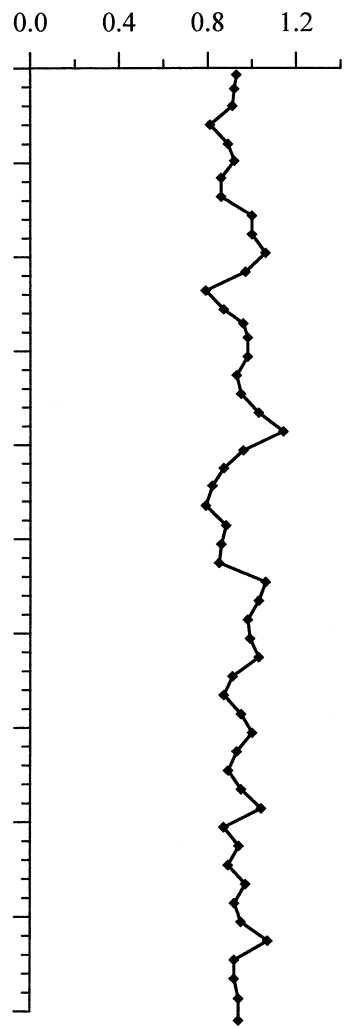

Fig. 2. ${ }^{230} \mathrm{Th}_{\mathrm{ex}}$ activity, magnetic susceptibility, ${ }^{230} \mathrm{Th}_{\mathrm{ex}}$ activity normalised to volume magnetic susceptibility and bulk dry density plotted vs. depth in core ANTA91-8. 


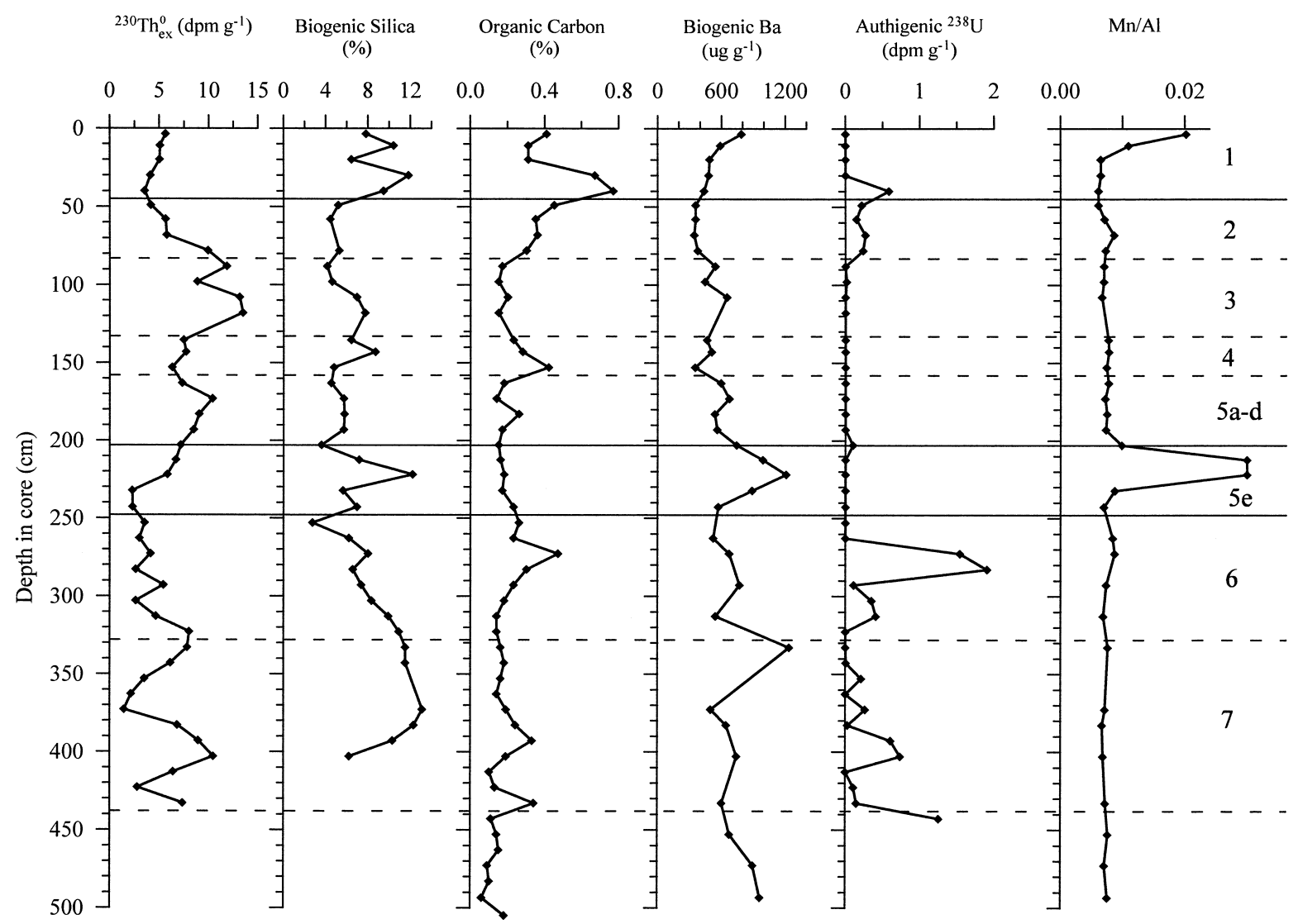

Fig. 3. Profiles of decay corrected ${ }^{230} \mathrm{Th}_{\mathrm{ex}}$, biogenic silica, organic carbon, biogenic Ba and authigenic ${ }^{238} \mathrm{U}$ concentrations together with the $\mathrm{Mn}$ /Al ratio vs. depth in core ANTA91-8. Lines mark the main isotope stage transitions following Martinson et al. (1987).

very similar at the core top and at around $250 \mathrm{~cm}$ depth. This, together with the rough ${ }^{230} \mathrm{Th}_{\mathrm{ex}}$ age model, makes possible the unambiguous identification of substage $5 \mathrm{e}$, and shows that the palaeoenvironmental processes during stage $1(0-45 \mathrm{~cm})$ and 5 e $(203-248 \mathrm{~cm})$ have been similar in the Ross Sea. For the period between $12 \mathrm{kyr}$ and $111 \mathrm{kyr}$ BP (45 to $203 \mathrm{~cm}$ depth), unambiguous time markers were not identifiable. Below the core sections corresponding to stages 1 and $5 \mathrm{e}$, the relatively thick layers containing authigenic $U$ were used to tentatively define the boundaries of stages 2 and 6 , respectively. We thereby assumed that an oxygen depletion of the glacial bottom water was the reason for these $U$ enrichments. The transition from stage 8 to 7 is much more uncertain and was fixed at $438 \mathrm{~cm}$ depth, from the ${ }^{230} \mathrm{Th}_{\mathrm{ex}}$ chronology. Applying this procedure we were able to evaluate average sedimentation rates for the identified climatic stages (Table 2). In the interval $0-438 \mathrm{~cm}$, the average rate was $1.8 \mathrm{~cm}$ $\mathrm{kyr}^{-1}$.

Table 2

Glacial-interglacial setting of core Anta91-8

\begin{tabular}{lccl}
\hline $\begin{array}{l}\text { Climatic } \\
\text { stage }\end{array}$ & $\begin{array}{l}\text { Age interval } \\
(\mathrm{kyr})\end{array}$ & $\begin{array}{l}\text { Core section } \\
(\mathrm{cm})\end{array}$ & $\begin{array}{l}\text { Sedimentation rate } \\
(\mathrm{cm} \mathrm{kyr}\end{array}$ \\
\hline 1 & $0-12$ & $0-45$ & 3.8 \\
2 & $12-24$ & $45-83$ & 3.2 \\
3 & $24-59$ & $83-133$ & 1.4 \\
4 & $59-74$ & $133-158$ & 1.7 \\
$5 \mathrm{a}-\mathrm{d}$ & $74-111$ & $158-203$ & 1.2 \\
$5 \mathrm{e}$ & $111-130$ & $203-248$ & 2.4 \\
6 & $130-190$ & $248-328$ & 1.3 \\
7 & $190-244$ & $328-438$ & 2.0 \\
\hline
\end{tabular}

Stage boundaries were obtained comparing the depth distributions of ${ }^{230} \mathrm{Th}_{\mathrm{ex}}^{0}$, biogenic silica and $\mathrm{Ba}$, organic carbon, $\mathrm{Mn}$ and authigenic uranium to the $\delta^{18} \mathrm{O}$ record of Martinson et al. (1987). 


\subsection{Fluxes to the sediments}

From ${ }^{230} \mathrm{Th}_{\mathrm{ex}}$ activities, sedimentation rates $(\mathrm{Ta}-$ ble 2) and bulk dry densities, the average ${ }^{230} \mathrm{Th}_{\mathrm{ex}}$ fluxes for each climatic stage were calculated (Fig. 4). Their deviation ( 0.8 to 2.3 times) by the value expected from the production in the water column suggests that processes of winnowing and focusing have been at work during different periods with variable intensity.

In order to calculate the sedimentation rate for each sediment section, we applied a ${ }^{230} \mathrm{Th}_{\mathrm{ex}}$ constant flux model, which assumes that within each isotopic stage the ${ }^{230} \mathrm{Th}_{\mathrm{ex}}$ flux to the sediment is only related

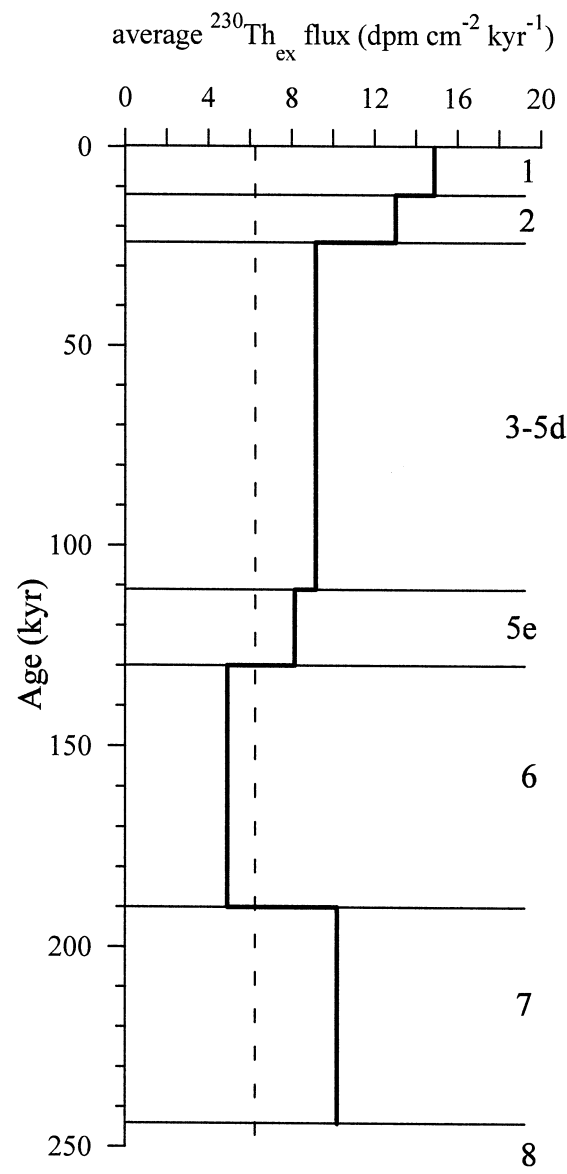

Fig. 4. Distribution, as a function of age, of average ${ }^{230} \mathrm{Th}_{\mathrm{ex}}$ fluxes calculated for each isotope stage. The dashed line represents the expected flux from production in the water column overlying the sediment $\left(6.25 \mathrm{dpm} \mathrm{m}^{-2} \mathrm{kyr}^{-1}\right)$. to its production in the overlying water column. This means that the variations of the ${ }^{230} \mathrm{Th}_{\mathrm{ex}}$ concentration within the isotope stages were interpreted as variations of the sedimention rate (Bacon, 1984; Francois et al., 1993; Frank et al., 1996). Boundary scavenging, which may have influenced ${ }^{230} \mathrm{Th}$ flux to the sediments, was considered negligible because here mass accumulation rates are low, compared to upwelling areas, where ${ }^{230} \mathrm{Th}$ boundary scavenging may occur.

Based on these derived ${ }^{230}$ Th sedimentation rates we were able to calculate the fluxes of particles, biogenic silica, biogenic $\mathrm{Ba}$ and organic carbon. Then, in order to obtain the component of the flux derived from overlying water column, these fluxes were normalised to the ratio between measured and expected flux of ${ }^{230} \mathrm{Th}_{\mathrm{ex}}$ (Bacon, 1984; Francois et al., 1993). The latter corresponds to the rate of production of ${ }^{230} \mathrm{Th}$ in the water column from decay of ${ }^{234} \mathrm{U}\left(2.6 \mathrm{dpm} \mathrm{cm}^{-2} \mathrm{kyr}^{-1}\right.$ per kilometer of water depth). Fig. 5 shows the variations of the corrected accumulation rates of particles, biogenic $\mathrm{Ba}$, biogenic silica and organic carbon. These corrected accumulation rates do not account for variable dissolution of labile organic matter. At the beginning of isotope stage 1 , substage $5 \mathrm{e}$ and, with a higher uncertainty, in the middle of stage 7 , a peak in the corrected accumulation rates is visible. Presently we are not able to explain the relatively high values of most parameters during stage 6 .

If the corrected accumulation rates of biogenic $\mathrm{Ba}$ and the bulk sediment fluxes (to account for biogenic Ba preservation) are translated into export productivity (Francois et al., 1995; Nürnberg et al., submitted), despite uncertainties concerning the biogenic $\mathrm{Ba}$ geochemistry, it appears that the values generally vary between 1 and $10 \mathrm{~g} \mathrm{C} \mathrm{m}^{-2} \mathrm{yr}^{-1}$ (Fig. 5). These values are relatively low compared to the export productivity at the APF in the Atlantic sector of the Southern Ocean (Nürnberg et al., submitted).

\subsection{Redox-sensitive elements}

Authigenic uranium and $\mathrm{Mn}$ (normalised to $\mathrm{Al}$ to correct for terrigenous inputs) are tracers of redox conditions and in recent papers (Kumar et al., 1995; Rosenthal et al., 1995; Frank, 1996) their distributions have been used to infer export palaeoproductiv- 


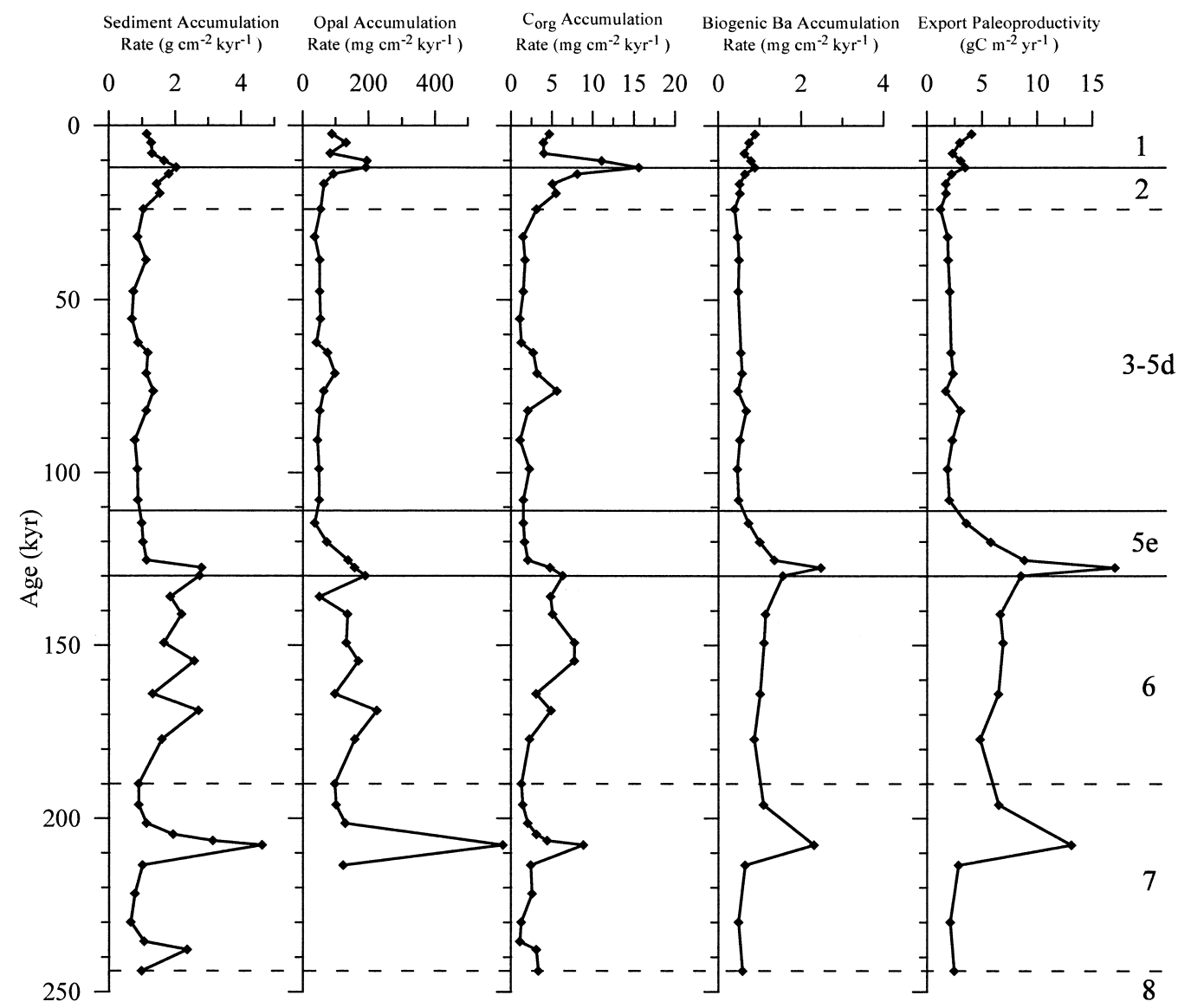

Fig. 5. Corrected accumulation rates of bulk sediment, biogenic silica, organic carbon and biogenic Ba, and export palaeoproductivity are plotted vs. age in core ANTA91-8. Lines mark the main isotope stage transitions following Martinson et al. (1987).

ity. Peaks of Mn overlying sections with high amounts of authigenic uranium and organic carbon were frequently described in sediments of the Northern Atlantic (e.g., Thomson et al., 1990) and recently in the Southern Ocean (Rosenthal et al., 1995). The generally accepted explanation for these distributions is that uranium, which is mobile under oxic conditions, precipitates from the pore water if reducing conditions form close to the sediment-water interface (Cochran and Krishnaswami, 1980). Higher organic carbon concentrations may be due to either oxygen depletion in bottom water or relatively higher flux of organic matter into the sediment, or both. Peaks of Mn reflect post-depositional remobilisation in the reducing sediment, followed by precipitation of Mn-oxide at the redoxcline (Froelich et al., 1979).
The depth profiles of $\mathrm{Mn} / \mathrm{Al}$ and authigenic ${ }^{238} \mathrm{U}$ of core ANTA91-8 are plotted in Fig. 3. The Mn/Al ratio displays two peaks, over a lithogenic background ratio of 0.006 in stage 1 and at the beginning of stage 5e. Deglacial peaks of authigenic ${ }^{238} U$ and organic carbon concentration corroborate a higher biogenic flux whereas the enrichment in the two underlying sections corresponds to glacial stages, where we have inferred low biological productivity. This supports the hypothesis of reduced bottom-water $\mathrm{O}_{2}$ persisting during the glacials.

Though $\mathrm{U}$ and $\mathrm{Mn}$ behaviours are connected, in one case (at the boundary between stages 6 and 5) $\mathrm{U}$ and $\mathrm{Mn}$ peaks are $30 \mathrm{~cm}$ apart. One explanation might be that reducing conditions still prevailed for a certain period of time after the deposition of the 
authigenic U, which gave way to further post-depositional upward migration of $\mathrm{Mn}$.

\section{Conclusions}

We investigated a sediment core (ANTA91-8) from the western part of the continental slope of the Ross Sea, where less detailed palaeoceanographical work, compared to the Weddell Sea margin, has been done up to now.

The ${ }^{230} \mathrm{Th}_{\text {ex }}$-based sediment chronology shows that the last two climatic cycles are recorded. The detailed record of the sediment core shows that peaks of concentrations and fluxes of organic carbon, biogenic $\mathrm{Ba}$, biogenic silica and $\mathrm{Mn}$ can be explained by a stratigraphy based on enhanced biological component fluxes during deglacial and interglacial periods. The distributions of authigenic $\mathrm{Mn}$ and $U$ help to mark isotope stages 6 and 2, assuming that a slower circulation pattern and a reduced oxygen-content of the bottom water probably persisted during glacials.

Sediment focusing prevailed at the site during most isotope stages. Focusing-corrected accumulation rates of biogenic components and thus also palaeoproductivity ( 1 and $10 \mathrm{~g} \mathrm{C} \mathrm{m}^{-2} \mathrm{yr}^{-1}$ ), were low relative to the APF in the Atlantic sector, throughout the last two climatic cycles. There is evidence of enhanced productivity at the beginning of interglacial stages 1, 5, and in the middle of stage 7 as deduced from the corrected accumulation rates of biogenic components, which are probably linked to longer periods of seasonally sea ice free conditions in this part of the Ross Sea margin.

\section{Acknowledgements}

The authors wish to thank F. Giglio for helping in the analytical work and G. Zini for the drawings. We are deeply indebted to M. Rugters van der Loeff, J. van Bennekom and an anonymous reviewer, whose comments and suggestions greatly improved the original manuscript. Research carried out in the framework of a Project on Glaciology and Paleocli- matology of the Programma Nazionale di Ricerche in Antartide, and financially supported by ENEA through a cooperation agreement with the University of Milan. This is contribution N. 1133 of the Istituto di Geologia Marina of the CNR, Bologna.

\section{References}

Abelmann, A., Gersonde, R., 1991. Biosiliceous particle flux in the Southern Ocean. Mar. Chem. 35, 503-536.

Anderson, J.B., Kurtz, D.D., Weaver, F.M., 1979. Sedimentation on the Antarctic continental slope. SEPM Spec. Publ. 27, 265-283.

Bacon, M.P., 1984. Glacial to interglacial changes in carbonate and clay sedimentation in the Atlantic estimated from thorium230 measurements. Isot. Geosci. 2, 97-111.

Burckle, L.H., Burak, R.W., 1988. Fluctuations in Late Quaternary diatom abundance: stratigraphic and paleoclimatic implications from subantarctic deep sea cores. Palaeogeogr., Palaeoclimatol., Palaeoecol. 67, 147-156.

Charles, C.D., Froelich, P.N., Zibello, A., Mortlock, R.A., Morley, J.J., 1991. Biogenic opal in Southern Ocean sediments over the last 450,000 years: implications for surface water chemistry and circulation. Paleoceanography 6, 697-728.

Cochran, J.K., Krishnaswami, S., 1980. Radium, thorium, uranium and $\mathrm{Pb}-210$ in deep-sea sediments and sediment pore waters from the north equatorial Pacific. Am. J. Sci. 280, 849-889.

Dehairs, F., Stroobants, N., Goeyens, L., 1991. Suspended barite as a tracer of biological activity in the Southern Ocean. Mar. Chem. 35, 399-410.

DeMaster, D.J., 1979. The marine budgets of silica and ${ }^{32} \mathrm{Si}$. PhD Thesis, Yale University, New Haven, CT, 308 pp.

DeMaster, D.J., 1981. The supply and accumulation of silica in the marine environment. Geochim. Cosmochim. Acta 45, 1715-1732.

DeMaster, D.J., Nelson, T.M., Harden, S.L., Nittrouer, C.A., 1991. The cycling and accumulation of biogenic silica and organic carbon in Antarctic deep-sea and continental margin environments. Mar. Chem. 35, 489-502.

Dymond, J., Suess, E., Lyle, M., 1992. Barium in the deep-sea sediments: a geochemical proxy for paleoproductivity. Paleoceanography 7, 163-181.

Francois, R., Bacon, M.P., Altabet, M.A., Labeyrie, L.D., 1993. Glacial/interglacial changes in sediment rain rate in the SW Indian sector of Subantarctic waters as recorded by ${ }^{230} \mathrm{Th}$, ${ }^{231} \mathrm{~Pa}, \mathrm{U}$, and $\delta^{15} \mathrm{~N}$. Paleoceanography 8, 611-629.

Francois, R., Honjo, S., Manganini, S.J., Ravizza, G.E., 1995. Biogenic barium fluxes to the deep sea: implications for paleoproductivity reconstruction. Global Biochem. Cycles 9, 289-303.

Frank, M., Eckhardt, J.D., Eisenhauer, A., Kubik, P.W., DittrichHannen, B., Mangini, A., 1994. ${ }^{10} \mathrm{Be},{ }^{230} \mathrm{Th}$ and ${ }^{231} \mathrm{~Pa}$ in 
Galapagos Microplate sediments: implications for hydrothermal activity and paleoproductivity changes during the last 100,000 years. Paleoceanography 9, 559-578.

Frank, M., Eisenhauer, A., Bonn, W.J., Walter, P., Grobe, H., Kubik, P.W., Dittrich-Hannen, B., Mangini, A., 1995. Sediment redistribution versus paleoproductivity change: Weddell Sea margin sediment stratigraphy for the last 250,000 years deduced from ${ }^{230} \mathrm{Th}_{\mathrm{ex}},{ }^{10} \mathrm{Be}$ and biogenic barium profiles. Earth Planet. Sci. Lett. 136, 559-573.

Frank, M., 1996. Reconstruction of late Quaternary environmental conditions applying the natural radionuclides ${ }^{230} \mathrm{Th},{ }^{10} \mathrm{Be}$, ${ }^{231} \mathrm{~Pa}$ and ${ }^{238} \mathrm{U}$ : a study of deep-sea sediments from the eastern sector of the Antarctic Circumpolar Current System. Rep. Polar Res., Alfred Wegener Institute for Polar and Marine Research, Bremerhaven, 186, 138 pp.

Frank, M., Gersonde, R., Rutgers van der Loeff, M., Kuhn, G., Mangini, A., 1996. Late Quaternary sediment dating and quantification of lateral sediment redistribution applying ${ }^{230} \mathrm{Th}_{\mathrm{ex}}$ : a study from the eastern Atlantic Sector of the Southern Ocean. Geol. Rundsch. 85, 554-566.

Froelich, P.N., Klinkhammer, G.P., Bender, M.L., Luedtke, N.A., Heath, G.R., Cullen, D., Dauphin, P., Hammond, D., Hartman, B., Maynard, V., 1979. Early oxidation of organic matter in pelagic sediments of the eastern equatorial Atlantic: suboxic diagenesis. Geochim. Cosmochim. Acta 43, 1075-1090.

Frignani, M., Guilizzoni, P., Lami, A., Oldfield, F., Ravaioli, M., 1995. Suitability of recent sediments from four northern Italian lakes for paleoenvironmental research: some preliminary results. Final Proc. III Workshop Clima, Ambiente e Territorio nel Mezzogiorno, Potenza, Italy, 703-727.

Grobe, H., Mackensen, A., 1992. Late Quaternary climatic cycles as recorded in sediments from the Antarctic continental margin. The Antarctic paleoenvironment: a perspective on global change. Antarctic Res. Ser. 56, 349-376.

Jacobs, S.S., 1991. On the nature and significance of the Antarctic Slope Front. Mar. Chem. 35, 9-24.

Kumar, N., Gwiazda, R., Anderson, R.F., Froelich, P.N., 1993. ${ }^{231} \mathrm{~Pa} /{ }^{230} \mathrm{Th}$ ratios in sediments as a proxy for past changes in Southern Ocean productivity. Nature 362, 45-48.

Kumar, N., Anderson, R.F., Mortlock, R.A., Froelich, P.N., Kubik, P., Dittrich-Hannen, B., Suter, M., 1995. Increased bio- logical productivity and export production in the glacial Southern Ocean. Nature 378, 675-680.

Ledford-Hoffman, P.A., DeMaster, D.J., Nittrouer, C.A., 1986. Biogenic silica accumulation in the Ross Sea and the importance of Antarctic continental-shelf deposits in the marine silica budget. Geochim. Cosmochim. Acta 50, 2099-2110.

Martinson, D.G., Pisias, N.G., Hays, J.D., Imbrie, J., Moore, T.C. Jr., Shackleton, N.J., 1987. Age dating and the orbital theory of the ice ages: development of a high-resolution 0 to 300,000-year chronostratigraphy. Quat. Res. 27, 1-29.

Mortlock, R.A., Charles, C.D., Froelich, P.N., Zibello, M.A., Saltzman, J., Hays, J.D., Burckle, L.H., 1991. Evidence for lower productivity in the Antarctic Ocean during the last glaciation. Nature 351, 220-223.

Nürnberg, C.C., Bohrmann, G., Frank, M., Schlueter, M. New productivity estimates based on barium flux in the Atlantic Sector of the Southern Ocean-Results from 190,000 year records, Paleoceanography (submitted).

Pudsey, C., 1992. Late Quaternary changes in Antarctic Bottom Water velocity inferred from sediment grain size in the northern Weddell Sea. Mar. Geol. 107, 9-33.

Pedersen, T.F., Calvert, S.E., 1990. Anoxia versus productivity: what controls the formation of organic-carbon-rich sediments and sedimentary rocks. Am. Assoc. Petrol. Geol. Bull. 74, 454-466.

Rosenthal, Y., Boyle, E.A., Labeyrie, L., Oppo, D., 1995. Glacial enrichments of authigenic $\mathrm{Cd}$ and $\mathrm{U}$ in subantarctic sediment: a climatic control on the elements' oceanic budget? Paleoceanography 10, 395-413.

Shimmield, G.B., Derrick, S., Mackensen, A., Grobe, H., Pudsey, C., 1994. The history of barium, biogenic silica and organic carbon accumulation in the Weddell Sea and Antarctic Ocean over the last 150,000 years. In: Zahn, R., et al. (Eds.), Carbon Cycling in the Glacial Ocean: Constraints on the Ocean's Role in Global Change. NATO ASI Series, Vol. I17. SpringerVerlag, Berlin, 555-574.

Strickland, J.D.H., Parsons, T.R., 1972. A practical handbook of seawater analysis. Bull. Fish. Res. Bd. 167, 311.

Thomson, J., Wallace, H.E., Colley, S., Toole, J., 1990. Authigenic uranium in Atlantic sediments of the last glacial stage: a diagenetic phenomenon. Earth Planet. Sci. Lett. 98, 222-232. 